\title{
Making natural markets: flexibility as labour market truth
}

\author{
KERRY RITTICH* \\ Faculty of Law, University of Toronto, Canada
}

\begin{abstract}
Introduction
ne of the most powerful and retentive ideas in contemporary discourse and consciousness is the idea of the market as an independent entity, something with its own logic, its own laws and its own requirements. In the last generation, this idea has surfaced as the pre-eminent organising force in the formulation and defence of policy. References to market forces, the demands of markets and, above all, the risks entailed by proposing initiatives that run counter to the internal laws of the market thread their way through the analysis of topics from tax law to social welfare policy.

What is new and distinctive is the epistemological dimension of this idea: a set of legal and institutional arrangements that has been conceptually and semantically allied with the properties and demands of the market now circulates in the form of knowledge claims. ${ }^{1}$ These knowledge claims are both well disseminated within the policy mainstream and deeply internalised by the technocratic class, so much so that they serve as a framework or set of outer boundaries defining the effective space of policy and regulatory action. At the same time, the market is increasingly adopted as an internal organising principle, one with tentacular reach in the realm of public administration as well as within private institutions.

The social against the market is a conventional, and convenient, way to describe the dynamics that animate market-based societies. Observations such as the following are commonplace. Markets are embedded in society. Markets are permeated with social norms. Markets depend on social trust. Markets build, and are built by, a robust civil society. Such observations are revealing: they capture the multiple facets and deep interpenetration of the social and the economic even as they end up marking them as

* Deep thanks to Diamond Ashiagbor, Amar Bhatia, Ruth Dukes, Prabha Kotiswaran and Amanda PerryKessaris for comments and suggestions and to the Social Sciences and Humanities Research Council of Canada for research support.

1 Organization for Economic Co-operation and Development (OECD), Regulatory Policy and the Road to Sustainable Growth Draft Report (OECD 2010) <www.oecd.org/regreform/ policyconference/46270065.pdf>; World Bank, World Development Report: Workers in an Integrating World (1995); World Bank, World Development Report 2002: Building Institutions for Markets (2001); World Bank Group, Doing Business: Measuring Business Regulations, <www.doingbusiness.org/>; World Bank, World Development Report 2013: Jobs (World Bank 2012) <http://publications.worldbank.org/ index.php?main_page=product_info\&products_id=24394>.
\end{abstract}


distinct forces or entities. This social/market polarity also operates at the level of law, policy, and governance. We routinely distinguish the rules and regulations needed to build and support the operation of markets from the social rights, social policy, social programmes and social initiatives whose purpose is to ameliorate the effects of market forces on communities and individuals.

Yet, although this heuristic has a certain historical plausibility, as an account of the rise of social rights and social policy in the industrialisation of Europe, ${ }^{2}$ if not always beyond, ${ }^{3}$ it may now have diminishing utility and traction. There are, I suggest, a number of reasons to revisit the social/market dichotomy at this time. The rise of the market as the metric of the rationality of law and policy now poses a deep challenge to labour market institutions and social policies that are seen to run against the grain of market dynamics. The many social projects and programmes that are infused with market principles and the growing use of social initiatives for market-centred projects and initiatives also put immense pressure on any framework of analysis organised around a market/social polarity. But a dichotomous conception of the market and the social has inherent limits in any event. At this point, we may need a less oppositional model, one that better reflects the complex social and economic operations both within and beyond markets, and the Möbius strip-like way that governance initiatives can seamlessly reflect and combine social and market logics.

This paper follows two intertwined issues. The first is the rise of the market as a truth claim - as a natural force, as an entity subject to natural laws to be interfered with at great peril, and as a set of boundaries and constraints on policy-making and law reform - as it now operates in the realm of labour market governance. The second is the impact of that ideational transformation on the market-social framework that, through the analysis of Polanyi and others, is familiar to us both as an intellectual construct and as a way of conceptualising law and policy. If the result is a need to capture the interpenetration of the social and the market in a deeper way, then one productive way to do so is by looking at the efforts to change the legal institutions that both define and connect them. Because legal rules and norms, formal and informal, structure both markets and social relations, tracking the effects of legal reforms provides a means to observe their shifting structures and dynamics from the inside out. Even where reforms do not succeed at transforming social and economic relations as intended, reform logics and agendas provide priceless clues as to how workers, societies and markets are imagined and valuable insights into the pressures that may be brought to bear on them. An examination of the ways that the market and the social are structured by law is, I suggest, also a promising way to illuminate the questions of social conflict and distributive justice that lie at the heart of debates about the market and the social.

Labour market conflicts have long been at the centre of debates about the place of social issues, the permissibility and limits of regulating economic relations in particular, ${ }^{4}$ and labour market policy remains an unusually instructive place to trace the evolving relationship between the social and the market. Work and workplace policy and regulation provide a dense transit point for concerns about growth, productivity, efficiency and competition on the one hand and welfare, solidarity, equality, human dignity and

2 T H Marshall, 'Citizenship and Social Class' in Class, Citizenship and Social Development (Anchor 1965).

3 Dipesh Chakrabarty, Provincializing Europe: Postcolonial Thought and Historical Difference (Princeton University Press 2008/2000).

4 Lochner v New York (1905) 198 US 45, 75. For a discussion of this and other early US labour cases, see E M Kelman, 'American Labor Law and Legal Formalism: How "Legal Logic" Shaped and Vitiated the Rights of American Workers' (1983) 58 St John’s Law Review 1-68. 
democracy on the other. Labour markets are, of course, markets. But labour is a distinctive, even 'fictitious' commodity, ${ }^{5}$ one that is fundamentally inseparable from the human that performs it. ${ }^{6}$ While the sale of labour makes work subject to economic calculation and rationality, labour markets are unusually complex institutions that are replete with - indeed organised by - moral, social and cultural norms and practices. ${ }^{7}$ Finally, work and labour markets are subjects of imagination and representation too. Thinking of work and labour markets as actively imagined highlights the role that cognitive frameworks might play in defining the horizon of regulatory possibilities; it also provides a vantage point from which to see how law might be used to advance new concepts of subjectivity and community at work.

\section{Locating the social and the economic}

Since at least the end of the nineteenth century, the market and the social have been defined as separate, and typically opposing, spheres. ${ }^{8}$ Formerly synonymous with the economy, the household became separated out and conceptualised as a private sphere, as wage labour outside the home became an increasingly normal and pervasive phenomenon in the context of industrialisation and the spread of capitalism. ${ }^{9}$ Different logics, moreover, were soon attributed to these spheres: while the market was the locus of selfinterest, governed by the logic of utility maximisation, the family and the household became identified as the repository of moral values such as altruism and sharing. ${ }^{10}$

Once the pathologies of untrammelled market forces were revealed, it was not long before the social was imagined not just as the opposite but as a corrective to the market. As the social problems generated by the conflict between labour and capital began to receive sustained attention as a set of conjoined ethical and moral problems, ${ }^{11}$ there was a global trend, evident at least in retrospect, toward incorporating social concerns into the responsibilities and political agendas of states. This trend took shape through law, as classical legal thought, dominant in the second half of the nineteenth century both as a mode of articulating the relation of the public to the private and as a technique for sharply delimiting the sphere of legitimate state action, was displaced by a new logic that accommodated, and ultimately balanced, a variety of social objectives in the adjudication of private rights. ${ }^{12}$

5 Karl Polanyi, The Great Transformation (Beacon Press 1944/1957).

6 Karl Marx, Economic and Philosophic Manuscripts of 1844 (Progress Publishers 1844/1959) $<$ hwww.marxists.org/archive/marx/works/1844/manuscripts/preface.htm>; Hannah Arendt, The Human Condition (University of Chicago Press 1958).

7 Jens Beckert, 'What is Sociological about Economic Sociology? Uncertainty and the Embeddedness of Economic Action' (1996) 25 Theory and Society 803-40; Jens Beckert, 'The Moral Embeddedness of Markets' MPIfG Discussion Paper 05/6: 5-20 (2005) <www.mpifg.de/pu/dp_abstracts/dp05-6.asp>.

8 Michel Foucault, The Birth of Biopolitics: Lectures at the College de France, 1978-79, Michel Senellart (ed), Graham Burchell (trans) (Palgrave Macmillan 2008) 240.

9 Nancy Folbre, 'The Unproductive Housewife: Her Evolution in 19th Century Economic Thought' (1991) 16 Signs 463-84.

10 Gary S Becker, A Treatise on the Family (Harvard University Press 1981). For an analysis and critique of this position, see Philomila Tsoukala, 'Gary Becker, Legal Feminism, and the Costs of Moralizing Care' (2007) 16 Columbia Journal of Gender and the Law 357-659; for a discussion of the production of this distinction in American law, see Janet Halley, 'What is Family Law? A Genealogy Part I' (2011) 23 Yale Journal of Law and the Humanities 1-109.

11 See, for example, De Rerum Novarum, the Vatican encyclical, published in 1891.

12 Duncan Kennedy, 'The Disenchantment of Logically Formal Legal Rationality, or Max Weber's Sociology in the Genealogy of the Contemporary Mode of Western Legal Thought' (2004) 55 Hastings Law Journal 1031-39; Duncan Kennedy, 'Three Globalizations of Legal Thought: 1850-2000' in D M Trubek and A Santos, The New Law and Economic Development: A Critical Appraisal (Cambridge University Press 2006). 
A conventional way to articulate the relationship between the market and the social, one popularised by Polanyi is in terms of force and counter-force: ${ }^{13}$ a convulsion or upheaval generated by the extension of markets to new domains, or the intensification of market forces in existing ones, surfaces as an evident threat to both society and economy. This threat provokes a counter-reaction emanating from 'spontaneous' or disorganised but powerful social forces. ${ }^{14}$ These processes of revolution and counter-revolution can both be envisioned in legal terms. As Polanyi recounts, the initial expansion of the market itself depended on continuous state action in the realm of law and policy. ${ }^{15}$ But the countervailing response in the name of the social ultimately took legal form as well. From the Reform Acts of early Victorian England that first introduced restrictions on the labour of women and children to the social rights entrenched across the industrialised world in the wake of the depression and subsequent war of the 1930s and 1940s, the social and the market were both expressed and consolidated as legal artefacts.

In this account, the social and the market are located in different legal instruments; they are also governed by different logics. Private law rights play a foundational role in providing the security of exchange and certainty of reward that build markets in the first place, reducing the transaction costs that impede the process of exchange, especially among those not otherwise bound by social reputation and cultural norms; ${ }^{16}$ regulations governing competition and debtor-creditor relations and addressing a defined set of market failures perform similar functions. ${ }^{17}$ Public law interventions such as employment standards, collective bargaining laws and other workers' rights, by contrast, are understood to alter the consequences of market transactions and, sometimes, to confine the spaces in which market forces are permitted to operate. Implemented in the name of values such as equality, solidarity and distributive justice, their express purpose is to contain or interrupt the very processes that market-building rules set in motion.

As a classic example, take the post-war social contracts of the industrialised world. A protective and redistributive state was originally envisioned as a necessary counterweight to the destabilising processes set in motion at the international level. It was wellrecognised that trade liberalisation and the progressive integration of markets exposed workers, as well as societies as a whole, to competitive forces that imperilled traditional bases of economic and social security. ${ }^{18} \mathrm{~A}$ key objective of that state was the decommodification of labour, ${ }^{19}$ a process achieved principally by strengthening the labour market institutions that provide a countervailing source of legal power to that possessed by the employer and the introduction of a variety of social protections.

It is axiomatic within economic sociology that social norms impinge deeply on the operation of markets. ${ }^{20}$ Their effects are particularly marked in labour markets: social

13 Polanyi (n 5); Wolfgang Streeck, 'The Crises of Democratic Capitalism' (2011) 71 New Left Review 5-29.

14 Polanyi (n 5) 136.

15 Ibid ch 12.

16 Douglass North, Institutions, Institutional Change and Economic Performance (Cambridge University Press 1990).

17 Ibrahim F I Shihata, 'Law, Development, and the Role of the World Bank' in Complementary Reforms: Essays on Legal, Judicial, and Other Institutional Reforms (Kluwer 1997).

18 John Gerard Ruggie, 'International Regimes, Transactions, and Change: Embedded Liberalism in the Postwar Economic Order' (1982) 36 International Organization 379-415; Robert Howse, 'From Politics to Technocracy - and Back Again: The Fate of the Multilateral Trading Regime' (2002) 96 American Journal of International Law 94-117.

19 International Labour Conference, Declaration Concerning the Aims and Purposes of the International Labour Organization, Philadelphia 1944) <www.ilo.org/public/libdoc/ilo/1944/44B09_10_e_f.pdf>.

20 Mark Granovetter, 'Economic Action and Social Structure: The Problem of Embeddedness' (1985) 91 American Journal of Sociology 481-510. 
norms about fair effort ${ }^{21}$ and fair wages, ${ }^{22}$ for example, both have a profound impact on the labour contract and gender, racial and cultural norms and categories still routinely allocate different populations of workers - women and men, white and non-white, dominant and minority ethnicities, for example - into different forms of work. ${ }^{23}$ Market forces and changing market norms, processes and structures, for their part, continue to exercise transformative effects on individuals, households and communities by drawing new groups into wage labour, reorganising household time and priorities and changing gender relations as women, and sometimes men, take on new economic roles. ${ }^{24}$

Notwithstanding these evident interrelationships, it remains common in both legal and popular consciousness to conceptualise the market and the social as fundamentally separate domains. There is a set of processes underway now, however, that are transforming social and economic relations in ways that are not captured or well-analysed by imagining the social and the market in opposition. At this point, the rationality of the market is (more) hegemonic as a driver of reform to law and policy and social objectives are less often contraposed to economic objectives. Instead, social programmes are themselves subject to processes of economic calculation and rationality and social objectives are increasingly realised through market processes.

Before discussing this development, however, it is crucial to revisit the conception of law in this story.

\section{The endogeneity of law to markets}

One of the puzzles is the ongoing invocation of an entity known as the 'free market' and the tenacity of related ideals like a 'level playing field' when it comes to its legal rules and institutions. The global financial crisis has provoked interventions in key financial and industrial sectors in the major economies of the world so broad, so deep and so apparently essential to the operation of contemporary capitalist orders that the existence of such entities and ideals at the real world level would seem to have been conclusively refuted. Nonetheless, they remain not just in wide circulation but entrenched as regulatory touchstones.

On one level, the puzzle can be explained by the independent life and importance of ideas in contemporary global governance. But another possibility is that there is, in effect, a double-consciousness about law and markets now in circulation. For an alternative interpretation would be that virtually no one believes in the natural market. That is, no one thinks that there is a normatively or institutionally pure economic space in which the price mechanism mechanically calibrates the relationship between supply and demand; moreover, no one would want such a market if it could exist. Rather, everyone understands the critical role of rules and institutions in markets; more importantly, everyone comprehends the extent to which the outcomes of market transactions depend on how their governing rules and institutions are configured, and fights over those rules and institutions for that very reason.

21 George A Akerlof, 'Labor Contracts as Partial Gift Exchange' (1982) 97 Quarterly Journal of Economics 543-69.

22 Robert M Solow, The Labor Market as a Social Institution (Blackwell 1990).

23 Harald Bauder, 'Culture in the Labour Market: Segmentation Theory and Perspective of Place' (2001) 25 Progress in Human Geography 37-53.

24 For a collection of studies exploring this issue, see the symposium issue on family law, (2010) 58(4) American Journal of Comparative Law. 
There is a compelling argument that all such debates are better understood as contestable claims about the legal character of 'normal' markets. ${ }^{25}$ As realist ${ }^{26}$ and critical legal scholars, ${ }^{27}$ as well as some institutional ${ }^{28}$ and heterodox ${ }^{29}$ economists, have observed, the market is not an entity that is regulated by law; the market is itself always a mixed legal and economic institution. Although the realists were acute observers of social and economic context, their insights about the role of law and the state in the market were ultimately analytic rather than sociological. It is not merely true, as Polanyi observed, that the road to the free market was both made and kept open by continual state intervention; ${ }^{30}$ rather, the key role played by the state in the operation of markets is an unavoidable feature rather than a historical or contingent fact. All private power is ultimately public, as the juridical structure of private rights depends on decision-making and ratification in the public realm through the actions of judicial, legislative and bureaucratic or administrative organs. ${ }^{31}$

Under the received mainstream understanding, market-building rules are neutral as between market actors; only defined classes of legal rules - rules typically styled as regulatory 'interventions', among which 'social' interventions such as labour law stand out in particular - perform redistributive functions. As much as different constituencies dispute the advisability of such rules, moreover, they typically share this basic frame of reference about what they do. Contra this understanding, the realists demonstrated that many market institutions embed allocational choices and perform functions that are associated primarily with social law. To put it another way, the rules and institutions of markets do not merely provide the grid or infrastructure in which economic transactions take place; they do not even just generate unequal or undesirable economic outcomes that then need to be tempered by socially oriented rules and interventions. Rather, private law rules 'produce', directly and indirectly, variable distributions of income; 32 they promote and hinder the formation of associations and groups, including labour unions; 33 and they structure freedoms and prohibitions in ways 34 that market actors actively use in organising their relationships. As the realists and post-realists emphasised, the design of market institutions is a mode of constructing, altering or reinforcing the powers and entitlements of different market actors; sometimes it is even a way to create new resources out of whole cloth. ${ }^{35}$ Thus, any reform to legal institutions potentially affects

25 The classic analysis of this phenomenon, in the context of debates about the international trade regime, is found in Dan Tarullo, 'Beyond Normalcy in the Regulation of International Trade' (1987) 100 Harvard Law Review 546-628.

26 Joseph Singer, 'Legal Realism Now' (1988) 76 California Law Review 465-544; David Kennedy and William W Fisher III (eds), The Canon of American Legal Thought (Princeton University Press 2004).

27 Duncan Kennedy, 'Law and Economics from the Perspective of Critical Legal Studies' in P Newman (ed), The New Palgrave Dictionary of Economics and the Law vol 2 (Palgrave McMillan 1998); Dennis Davis and Karl Klare, 'Transformative Constitutionalism and the Common and Customary Law' (2010) 26 South African Journal of Human Rights 403-509.

28 Warren J Samuels, 'The Economy as a System of Power and its Legal Bases: The Legal Economics of Robert Lee Hale' (1972) 27 University of Miami Law Review 261-371.

29 Dean Baker, Taking Economics Seriously (MIT Press 2010).

30 Polanyi (n 5) ch 12.

31 Singer (n 26).

32 Ibid; Davis and Klare (n 27).

33 Kelman (n 4).

34 W N Hohfeld, 'Some Fundamental Legal Conceptions as Applied in Judicial Reasoning' (1913) 23 Yale Law Journal 16-59.

35 Robert Hale, 'Coercion and Distribution in a Supposedly Non-Coercive State' (1923) 38 Political Science Quarterly 470-94; Morris Cohen, 'Property and Sovereignty' (1927) 13 Cornell Law Quarterly 8. 
both access to resources and the distribution of income and may increase or diminish parties' exposure to a wide range of risks and opportunities. Moreover, the establishment of legal entitlements and default rules creates bargaining endowments with far-reaching effects; even where their presence is deeply receded or entirely invisible, parties are, as it were, always bargaining in their shadow. ${ }^{36}$

Attending to these constitutive and distributive properties of legal rules generates a number of insights into the mainstream representation of the market and its relation to the social. We can see that this representation naturalises a highly fluid realm, hypostasising something that, rather than a 'thing', is better imagined as a contingent and contestable set of forms and processes. Representing as found something that is in fact made and positing immutable market forces that must be contained, it ignores the way that both 'the market' and different actors within it gain and lose force through choices that are made in the design of market institutions. ${ }^{37}$

Once the market is viewed as a legal artefact, it becomes clearer how the structure and operation of the social, too, might be changed by decisions made in the realm of the market. For example, bargaining power within the household can be affected by economic opportunities enjoyed by, or denied to, individual members outside in the market. ${ }^{38}$ The responsibilities and preoccupations of families, even their structure and composition, may shift in response to the reallocation of risk and entitlements of market actors. ${ }^{39}$ Thus, taking note of the broader effects of market-constitutive legal rules has the collateral effect of demonstrating that the social is (partly) a legal artefact too. This, in turn, calls into question the persistent tendency to invoke the social as a natural force, something that is the source of law rather than, as has been observed at least since Weber, its product. ${ }^{40}$ The form, operation, even the nature of households and myriad other associations are all subject to change through legal and policy intervention.

Once this productive role of law is noted, it becomes easier to observe how market logics and processes of economic calculation might operate, or be introduced, within the social realm. As in the market, so in the family or household is behaviour subject to modification and incentivisation through legal and policy choices that are infused with economic rationality and calculation. ${ }^{41}$ Indeed, not just behaviour but fundamental conceptions of familial, social and political subjectivity and citizenship may be altered through such interventions.

\section{Foucault on the market as a principle of government}

In The Birth of Biopolitics, Michel Foucault sets out a genealogy of the rise of markets as an ordering principle of government, a phenomenon that, in his view, lies at the heart of what he calls 'liberal governmentality'. ${ }^{42}$ Foucault's central claim is that, circa the second half of the eighteenth century, the problem of rule or governmentality shifts. No longer

36 R Mnookin and L Kornhauser, 'Bargaining in the Shadow of the Law: The Case of Divorce' (1978-79) 88 Yale Law Journal 950-97.

37 Davis and Klare (n 27).

38 Bina Agarwal, "Bargaining" and Gender Relations within and beyond the Household' (1997) 3 Feminist Economics 1-51.

39 For an exercise exploring how family composition, structure and activities might be affected by economic development policy and strategy, see Kerry Rittich, 'Black Sites: Locating the Family and Family Law in Development’ (2010) 58 American Journal of Comparative Law 1023-54.

40 Kennedy (n 12).

41 Rittich (n 39).

42 Foucault (n 8). 
is it framed in terms of the rights of man against the sovereign or despot; nor is it a matter of raison d'etat, that is, the preoccupations of a state with an eye to its power, wealth and position vis-à-vis other states. Instead, governmentality comes to be about the limits of state action, the recognition and embrace of a self-limiting rationality that emanates from the properties or truths of the entities that are to be governed. Thus, the subjects of regulation themselves come to define the scope of legitimate government action. Chief among these entities is the market: as Foucault observed, 'the possibility of limitation and the question of truth are both introduced into governmental reason through political economy'. ${ }^{3}$

Internal to this transformation is an epistemological shift, one that drives a new way of understanding the task of rule itself. Before describing this new governmental rationality, Foucault places great stress on the market as a domain of truth, what he refers to as an agency of veridiction. ${ }^{44}$ What it means to be such an agency is precisely to be constituted as an entity that possesses natural properties that must be respected. Notice the active construction here: something must be constituted as such, must be imagined and accepted as an entity that could produce truths that then come to define the limits of state action.

Notice, too, how this rationality also introduces the idea that there might be a single way to think about the tasks of governance. Prior to the advent of liberal governmentality, the state or sovereign could be expected to adopt different logics and approaches in pursuit of its objectives. Not only would different objectives prevail at different times; there would be an array of strategies and styles of governing for realising them. The introduction of the new ordering principle, however, curbs the reach of the sovereign, curtailing its power to regulate the activities of its subjects. But it inevitably reduces the legitimate styles and strategies of governance at the same time: only some things become permissible to do, those that are consistent with the properties of the thing to be governed.

Foucault locates the emergence of political economy as the limiting power of liberal governmentality in a particular period of the eighteenth century. However, most of his analysis of its properties and characteristics is derived from a discussion of the rise of neoliberalism in the twentieth century, its German, French, UK and American histories and varieties in particular. Out of this discussion emerges an astonishingly prescient account of the logic(s) behind the neoliberal turn in global governance; one that both evokes the spirit of global governance avant la lettre and provides an informative guide to the rise of flexibility as a template for labour market governance.

\section{The market as a principle of governance: the case of labour market flexibility}

A congeries of objectives was served by labour market policy during the post-war 'golden age'. The generalised acceptance of Keynesian economic theory, both as a diagnostic of the causes of the depression of the 1930s and as a positive programme for macroeconomic management, meant that it was possible to identify the lineaments of a common approach to labour market and social policy across industrialised, marketbased states. While there were programmes of the left and the right, expressed in myriad national variations, there was also considerable consensus on the overall goals of labour market regulation, if not the precise balance to be struck between them. They included: full employment consistent with relative price stability; a floor under the 
labour contract to mitigate the problem of the working poor; legal support for collective bargaining to alleviate the disparity of bargaining power between labour and capital; insurance against foreseeable risks of disruption to income through events such as unemployment, disability, maternity and age; and income transfers to those outside the market altogether. In later years, anti-discrimination norms figured centrally as well. ${ }^{45}$ It is well-recognised that these policies were motivated as much by the desire to ensure the continuity of production and to maintain economic demand as to advance objectives explicitly understood as 'social'. They also, it must be said, served broader cultural and political objectives, from the maintenance (and, later, transformation) of gender and family relations to the prevention of more fundamental challenges to a capitalist economic order.

Beginning in the 1990s, in the wake of a broader transformation in governmental thinking and practice typically identified as neoliberalism or the Washington consensus, flexibility emerged as the fundamental ordering principle of labour market governance. ${ }^{46}$ Labour market flexibility might be thought of as the expression of economic rationality in the domain of labour markets. Flexibility norms aim to reverse the logic of decommodification of the social state and, through systemic modifications to labour market institutions and social policy, to induce greater responsiveness on the part of workers to market incentives. As a governance project, its logic is derived from the analytic framework that informs neoliberal regulatory policy in general, that is, a version of neoclassical and institutional economic analysis. ${ }^{47}$ Briefly stated, its operating premise is that labour market institutions such as employment standards and protections interfere with the optimal allocation of labour market resources. Unless responding to a defined set of market failures, they produce a series of labour market inefficiencies that generate both higher unemployment and depressed rates of economic growth. Collective action on the part of workers poses similar threats to the health of labour markets; for the same reasons, many social programmes, especially 'passive' as opposed to 'active' forms of income support, must be rethought or abandoned as well. 48

It is not that alternative visions and arguments about labour market institutions and workers' rights disappeared with the emergence of flexibility - far from it. At virtually the same time, for example, there was a call for the global recognition of 'core' labour rights or standards. But for the first time, a single organising rationale became visible in the field of labour market regulation, permeating and structuring debates about optimal labour

45 For a contemporary reflection on their enduring pertinence, see Robert Pollin, 'Back to Full Employment' (2011) Boston Review <www.bostonreview.net/BR36.1/pollin.php>.

46 For a foundational, and representative, document, see OECD, OECD Jobs Study - Evidence and Explanations. Part I: Labour Market Trends and Underlying Forces of Change; Part II: The Adjustment Potential of the Labour Market (OECD 1994). See also, World Bank, World Development Report: Workers in An Integrating World (World Bank $1995)<$ http://go.worldbank.org/3IVO4ONAZ0>; World Bank, Doing Business 2004: Understanding Regulation (World Bank 2004) <www.doingbusiness.org/reports/global-reports/doing-business-2004>; World Bank, Doing Business 2006: Creating Jobs (World Bank 2006) <https://openknowledge.worldbank.org/handle/10986/7421>; World Bank, Doing Business 2010: Reforming Through Difficult Times (World Bank 2010) <www.doingbusiness.org/reports/global-reports/doing-business2010>; OECD, Boosting Jobs and Incomes (OECD 2006).

47 Joseph E Stiglitz, Globalization and its Discontents (WW Norton \& Co 2002)

48 For engagements with this logic, see Guy Standing, Global Labour Flexibility: Seeking Distributive Justice (Macmillan 1999); Diamond Ashiagbor, The European Employment Strategy: Labour Market Regulation and New Governance (Oxford University Press 2005); Kerry Rittich, 'Rights, Risk and Reward: Governance Norms in the International Order and the Problem of Precarious Work' in Judy Fudge and Rosemary Owens (eds), Precarious Work, Women, and the New Economy: The Challenge to Legal Norms (Hart 2006); Kerry Rittich, 'Global Labour Policy as Social Policy’ (2008) 14 Canadian Labour and Employment Law Journal 227-75. 
and employment laws, the path of labour law reform and forms and functions of social policy as well. In the process, a field that had previously served multiple ends and reflected competing logics and disparate concerns was reconceptualised so that economic rationality became the grid of intelligibility for the making of law and policy.

In relatively short order, flexibility norms provoked a cognitive revolution in the realm of labour market governance, one that is now 'global' in a number of senses. Labour market flexibility originally took the form of labour market policy advice devised and championed by influential multilateral financial and economic institutions to both industrialised ${ }^{49}$ and developing states. ${ }^{50}$ Through a variety of instruments both hard and soft, from loan conditionalities, to policy surveillance, ${ }^{51}$ to the adoption of operational policies $^{52}$ and performance standards, ${ }^{53}$ to the conversion of flexibility into a general metric of good labour market regulation through the creation of governance indicators, ${ }^{54}$ flexibility norms quickly became transnationalised, visibly influencing the regulatory agendas of the industrialised, developing and emerging market states. ${ }^{55}$ At this point, both flexibility and many of its associated tenets are referred to simply as 'conventional wisdom'.56 That is, they have become the frame or baseline against which alternative conceptions of labour market governance must be explained, elaborated and defended.

Flexibility norms inform virtually all of labour market 'best practice' and knowledge dissemination projects, whether public or private. ${ }^{57}$ They also permeate regulatory initiatives in the private sphere. Although they often make reference to normative anchors such as the International Labour Organization (ILO) Declaration on Fundamental Principles and Rights at Work, corporate and industry codes of conduct are typically designed to both replace - or forestall - conventional forms of regulation and ensure that workplace norms and practices are responsive to changing market conditions. ${ }^{58}$ Dynamic, responsive norm-setting in light of emerging knowledge and changing market conditions is an operative premise of 'new governance' initiatives. ${ }^{59}$

49 OECD, Jobs Study (n 46); OECD, Boosting Jobs and Incomes (n 46); International Monetary Fund (IMF), World Economic Outlook 2004: Advancing Structural Reforms (IMF April 2004).

50 World Bank, World Development Report (n 45).

51 For a discussion of the IMF's Article IV consultations and its proposed labour market policy reforms in the context of the recent economic crises, see Marc Weisbrot and Helene Jorgenson, Macroeconomic Policy Advice and the Article IV Consultations: A European Union Case Study (Center for Economic and Policy Research 2013) <www.cepr.net/documents/publications/article-IV-2013-01.pdf>. For an earlier analysis, see Rittich, 'Rights, Risk and Reward' (n 48).

52 For a discussion of the use of operational standards in other areas and their impact on the development of international law, see Galit Sarfaty, 'The World Bank and the Internalization of Indigenous Rights Norms' (2005) 114 Yale Law Journal 1791-818.

53 International Finance Corporation, Performance Standard 2: Labor and Working Conditions (IFC 2012).

54 See Employing Workers' Indicator, World Bank, Doing Business (n 46) various years. For a discussion of its shortfalls at both the empirical and analytic levels, see Alvaro Santos, 'Labor Flexibility, Legal Reform, and Economic Development' (2009) 50 Virginia Journal of International Law 43-106.

55 Standing (n 48). For a discussion on labour market flexibility in the context of the European Union, see Diamond Ashiagbor, 'Promoting Precariousness? The Response of EU Employment Policies to Precarious Work' in Fudge and Owens (n 48).

56 World Bank, World Development Report 2013 (n 1) 37.

57 See for example, the UN Global Compact <www.unglobalcompact.org>; UN/UN Women, Women's Empowerment Principles<www.unifem.org/partnerships/womens_empowerment_principles>.

58 See, for example, Equator Principles: Environmental and Social Risk. Management for Project Finance <www.equatorprinciples.com>.

59 Gráinne de Búrca and Joanne Scott (eds), Law and New Governance in the EU and the US (Oxford University Press 2006); Cynthia Estlund, Regoverning the Workplace: From Self-Regulation to Co-Regulation (Yale University Press 2010). 
Labour market flexibility functions in a range of modes: it is at once a logic or explanatory rationale, a set of regulatory practices and a framework or metric for measuring the adequacy and functionality of labour market regulation. To borrow from Foucault, it involves the rise of a discourse and set of practices that 'on the one hand, constitutes those practices as bound together by an intelligible connection and, on the other hand, legislates and can legislate on these practices in terms of true and false'. ${ }^{60}$ Now, it is no longer a matter of making labour policy that balances a range of concerns and objectives, social, economic and political. But nor does labour policy simply reflect the triumph of a new (or old) set of interests and political forces. That is to say, labour market governance is no longer a domain that is formed out of conflict and contestation between the positions of labour and capital, left and right, neither of which is ever fully or finally dominant. Rather, it is labour policy that must be so because it is crafted in response to the putative traits and truths of labour markets themselves.

With the market as a generator of truth and a limitation on government, we have the ground prepared for an associated phenomenon, labour and social policy as a technocratic enterprise and a domain of expertise. ${ }^{61}$ As flexibility is diffused as a governance norm, labour law as a subject of politics and contestation recedes while experts and technocrats step forward to elucidate and elaborate the rules and policies to govern labour markets. In so doing, they confront a set of conundrums and decisions inherent in the building of any legal regime: they must decide how to construct rules and institutions out of higher-level normative and policy commitments. However, they address and resolve those questions and difficulties according to the cognitive frameworks and intellectual traditions that inform their understanding of the purposes and effects of labour market governance, evaluating and making distinctions among the options on offer, at the same time ruling out, or not even considering, those that seem at odds with those premises.

Here, it is important to distinguish the rise of flexibility as a paradigm of governance from the argument for flexibility in itself or, put otherwise, to note the transformation of flexibility from political or theoretical argument to epistemology. Arguments against workers' rights have long been in circulation. In classic 'rhetoric of reaction' mode, ${ }^{62}$ employers have routinely opposed labour market regulation on the grounds of futility, jeopardy and perversity, arguing that they will kill the goose - economic growth - that lays the golden egg of jobs; that they won't work - that is, improve the terms and conditions of work in any aggregate sense - because they will simply drive more employment into the grey or informal market; and that even if they did work, it would be bad rather than good for workers because they only protect labour market insiders at the expense of outsiders, not to mention consumers and society at large. While it is true that the rationale for labour market flexibility rests on all these bases, what is new, and distinctive, is the perception, derived from a broader policy context in which fidelity to economic rationality has become the touchstone for regulatory policy and reform, that flexibility is compelled by a proper understanding of labour markets themselves. Thus, a set of claims and arguments that for the better part of a century undergirded, at best, one pole of the debate about the social - namely, that labour market policy should be organised so as to maximise employer freedom to allocate labour resources, whether in the name of liberty

60 Foucault (n 8) 18.

61 David Kennedy, 'Challenging Expert Rule: The Politics of Global Governance' (2005) 27 Sydney Law Review 5-28. For a discussion of the centrality of expertise to the operation of the world trade regime, see Andrew Lang, World Trade Law after Neoliberalism (Oxford University Press 2011).

62 Albert O Hirschman, The Rhetoric of Reaction: Perversity, Futility, Jeopardy (Belknap 1991). 
of contract or policy goals such as increased efficiency and economic growth - now provides a general frame of reference for the consideration of questions of labour market regulation.

The dominance of flexibility as a labour market governance heuristic cannot be explained simply by the inherent superiority of the premises of neoclassical and institutional economics for explaining the operation of labour markets. There are persuasive, alternative explications of economic rationality within labour markets, ${ }^{63}$ indeed compelling critiques of the role of rationality in markets altogether. ${ }^{64}$ Even within mainstream economic theory, flexibility norms were subject to critique well before they were implemented in practice. ${ }^{65}$ Nor does flexibility prevail because of a shortage of contending political or institutional agendas. Those presently on offer range from the ILO's Decent Work Agenda, defending workers' rights, job creation, social dialogue and social protection, ${ }^{66}$ to the myriad decentralised, less formal, regimes and proposals championed by non-governmental organisations, industries, corporations and civil society groups, most of which make eclectic use of a range of workers' and human rights. ${ }^{67}$ Nor is it the case that empirical studies have conclusively borne out the connection between 'deregulatory' reforms and improved labour market outcomes. Those connections had always been tenuous and highly contingent; ${ }^{68}$ at this point, not even the exponents of flexibility invariably maintain them. ${ }^{69}$ That said, flexibility may well draw power precisely from the singularity of its focus on efficiency as the normative goal of labour market regulation. ${ }^{70}$ The apparent coherence of its objectives distinguishes it sharply from current social agendas, especially to the extent that questions of bargaining power have receded from view and the conflict between labour and capital no longer plays its historic galvanising role. Perhaps most important, flexibility is rooted in perceptions and practices that already have broad plausibility and popularity among elites and the technocracy in respect of economic governance writ large.

Rather, the dominance of labour market flexibility is about the making of truth, where 'truth' is understood to be a narrative about labour markets that is both internally coherent and consistent with the normative aspirations and institutional implications of other markets. A mixed political, institutional and intellectual or ideational project, flexibility is fundamentally as much about how to think about labour markets as it is about what to $d o$ with them. The production and dissemination of claims about the nature of markets in general has had a generative effect on the way that specific markets - their

63 Simon Deakin and Frank Wilkinson, 'Labour Law and Economic Theory: A Reappraisal' in H Collins, Paul Davies and Roger Rideout (eds), Legal Regulation of the Employment Relation (Kluwer Law International 2000); Simon Deakin and Frank Wilkinson, The Law of the Labour Market: Industrialization, Employment and Legal Evolution (Oxford University Press 2005); Bruce E Kaufman, 'Labor Law and Employment Regulation: Neoclassical and Institutional Perspectives' in K Dau-Schmidt, S Harris and O Lobel (eds), Labor and Employment Law and Economics (Edward Elgar 2009).

64 Cass R Sunstein (ed), Behavioural Law and Economics (Cambridge University Press 2000)

65 Joseph E Stiglitz, The Price of Inequality: How Today's Divided Society Endangers our Future (WW Norton \& Co 2012).

66 International Labour Organization, 'Decent Work Agenda' <www.ilo.org/global/about-the-ilo/decentwork-agenda/lang-en/index.htm>.

67 See, for example, the references to 'core' labour standards in UN Global Compact and in the Equator Principles on project finance.

68 David Howell, 'Unemployment and Labour Market Institutions: An Assessment' in David Howell (ed), Fighting Unemployment: The Limits of Free Market Orthodoxy (Oxford 2005); Baker (n 29).

69 See, for example, the discussion in World Bank, World Development Report 2013 (n 1) ch 8, 'Labor Policies Revisited'.

70 Kaufman (n 63) 6-8. 
properties, their dynamics - are conceptualised, powerfully shaping what features of labour markets come into view and what materialises as an issue to be addressed. These features and issues make institutional arrangements seem alternatively plausible and feasible or undesirable and unavailable and, in turn, generate both possibilities and constraints on workers' rights and the regulation of labour markets. ${ }^{71}$

\section{What are its effects?}

In the first place, economic rationality as the principle of labour market governance serves to unsettle, and dislodge, the loose set of commitments, institutional forms and practices associated with the social state of the embedded liberal bargain. Viewed from within the framework of flexibility, many of these commitments, forms and practices become, if not incompatible with the nature of markets, then inherently suboptimal things to pursue. Second, and more fundamentally, economic rationality resituates the objectives of labour law in relation to the market. Rather than something to be achieved by restraining market processes, better terms and conditions of work and greater economic security for workers and citizens become objectives to be realised in conjunction with, even directly through, market forces. Thus, the rationality associated with the market effectively becomes the metric by which what was once imagined as its opposite, the social, is itself measured.

At the macro-level, the properties attributed to labour markets play an essential role in the subordination or displacement of the historical objectives of labour law. As labour markets are imagined as just another species of market that, when well-functioning, generate positive welfare outcomes, we find new significance attributed to objectives such as the formalisation and extension of labour markets. ${ }^{72}$ Increased levels of worker participation and decreased levels of 'dependence', intensified competition among workers and greater sensitivity of the price of labour to market forces and signals become the engines of improved labour markets outcomes, ${ }^{73}$ while increased levels of skill and human capital are the route to higher productivity and both individual and national success. ${ }^{74}$ At the same time, the pursuit of distributive justice, social solidarity, rebalancing of bargaining power as between labour and capital, limits on the extent of working time and other baseline conditions of the labour contract, such as minimum wages, are demoted: such concerns read as incompatible with markets operating in their ideal, most efficient mode unless they manifest in the form of an extreme or 'core' individual labour rights violation like child labour or forced labour. For the same reason, it is unclear how a classic concern like labour exploitation could even be recognised; arbitraging differences in labour costs is the very point of the exercise.

71 For further discussion of the relation between factual claims and conventions, knowledge practices and governance, see Andrew Lang, 'The Legal Construction of Economic Rationalities?' (2013) 40 Journal of Law and Society 155-71.

72 Guillermo E Perry et al, Informality: Exit and Exclusion (World Bank 2007) <http://web.worldbank.org/WBSITE/EXTERNAL/COUNTRIES/LACEXT/0,,contentMDK:2134536 9 pagePK:146736 piPK:146830 theSitePK:258554,00.html>; United Nations Development Programme (UNDP) Commission on Legal Empowerment of the Poor, Making the Law Work for Everyone vol I (Commission on Legal Empowerment of the Poor/UNDP 2008).

73 World Bank, World Development Report 2013 (n 1); World Bank, Doing Business 2006 (n 46); World Bank, Doing Business 2010 ( $\mathrm{n}$ 46); Rittich (n 48); Weisbrot and Jorgenson ( $\mathrm{n}$ 51).

74 Thomas Courchene (ed), Policy Frameworks for a Knowledge Economy: Proceedings of a Conference held at Queen's University November 16-17, 1995. (John Deutsch Institute for the Study of Economic Policy 1996); World Bank, Building Knowledge Economies: Advanced Strategies for Development (World Bank 2007) <http://go.worldbank.org/F2BD1MEUE0>. 
The transformative work of flexibility norms is done largely at the mid-level, as the ideology of the natural market and respect for its properties sets the parameters for the permissible and impermissible legal and policy instruments that are available to advance labour market objectives. Simply put, the market is thought to authorise, indeed to require, some rights but not others. The resulting flexibility, however, is not a general flexibility but one that turns out to be highly liberating and enabling as regards capital and correlatively constraining and disempowering for workers. Here, it is useful to observe that a structure of private law rules revolving around strengthened contract and property rights has already been assumed as a background condition of markets. ${ }^{75}$ Far from neutral, these private law rules reliably strengthen those with greater economic resources and exit options. ${ }^{76}$ A place remains for basic non-discrimination rights, as they aid in the normalisation and realisation of the dream of fully inclusive and pervasive markets. But further labour market institutions cannot be easily assimilated to this image of the market; when they materialise, they do so first and foremost in their negative form. Thus, minimum non-waivable terms on wages and working conditions raise the cost of labour above its marginal product. Collective bargaining rules license anti-competitive behaviour to the same effect. Employment protection legislation, whether at hiring or termination, impairs the reallocation of labour and raises levels of unemployment.

The successful diffusion of flexibility as a labour market governance norm means that much discussion of legal institutions now takes place within the zone, and often in the language, of market imperfections. Both academic and institutional debate about labour market regulation increasingly revolves around transaction costs, beneficial and harmful externalities, collective action problems, information asymmetries, even occasionally asymmetries of bargaining power, and whether they should be recognised as species of market failure that warrant a legal or policy response. ${ }^{77}$ Here, it is the perfection of market processes, not their restraint, that is the main subject of interest: the question is the potential productivity and efficiency enhancements of institutional arrangements now damned under the conventions of flexibility. ${ }^{78}$ And even when other norms and values are acknowledged, the flexibility heuristic already ensures that, explicitly or implicitly, productivity and efficiency remain the yardsticks against which any choices and trade-offs are made. ${ }^{79}$

The prior notion of balancing of rights and interests, characteristic of the 'unsynthesized co-existence of transformed elements of classical legal thought and . . . the social' of the previous era has not, of course, disappeared. ${ }^{80}$ The institutional legacy of the post-war social contract persists in some form in many countries, ensuring channels for countervailing claims by workers through human and constitutional rights as well as statutory labour and employment rights. In these contexts, flexibility norms will not invariably prevail. Yet, the normalisation of flexibility has, arguably, shifted this balancing process; certainly it has potential to do so. Viewed through the prism of economic rationality, workers' rights to exert greater influence over the contract for

75 I Shihata, The World Bank in a Changing World vol I (1991), ch 6 - 'The World Bank and Private Sector Development - A Legal Perspective'; UNDP (n 72).

76 Adam Smith, Inquiry into the Nature and Causes of the Wealth of Nations (E P Dutton 1910/1776); Hale (n 35).

77 Deakin and Wilkinson, The Law of the Labour Market (n 63); Bob Hepple, Labour Laws and Global Trade (Hart 2005); Kaufman (n 63); World Bank, World Development Report 2013 (n 1).

78 Deakin and Wilkinson, The Law of the Labour Market (n 63); Hepple (n 77).

79 See, for example, the discussion in World Bank, World Development Report 2013 (n 1) ch 8, 'Labor Policies Revisited'.

80 Kennedy, 'Three Globalizations of Legal Thought' (n 12) 63. 
labour may carry diminished weight, especially to the extent that claims are framed simply in terms of opposing normative claims like dignity, democracy, or distributive justice. In a direct contest with employer contractual freedoms and rights of establishment, workers' rights may falter, their 'fundamental' character notwithstanding. ${ }^{81}$ And where they do prevail, workers' rights may not take their classic social form; instead, infused with a new rationale or justification, they may be confined or refashioned, either legislatively or through adjudication, in ways that make them compatible with the dominant consciousness about rational labour market policy.

\section{Labour market institutions as instruments of calculation}

If the original impetus behind labour market flexibility was the belief that labour market institutions lead to the misallocation of labour resources and, by extension, the pervasive underperformance of labour markets, a key element of the flexibility agenda is the promotion of reforms to make workers more responsive to market signals and market forces. The aim is not merely the repeal of rules that decommodify labour. Flexibility norms seek to use labour market institutions to actively mobilise competitive pressures on workers; still more, they seek to produce workers who identify as market actors, more intensively cultivate their human capital and exploit their own economic possibilities.

It may be this shift in logic, the discovery that labour market institutions can be used not to shield workers from market forces but to channel behaviour both within and beyond the labour market in more and more pervasively market-responsive ways, that is the enduring significance of flexibility as a governance project. ${ }^{82}$ Policy debates over the relationship between economic growth and social objectives, including over labour standards and human rights, are contested ${ }^{83}$ and rarely if ever fixed or finished 'for good', even within the institutions that promote flexibility and other good governance norms. ${ }^{84}$ Yet, even where there are concessions to the need for employment standards or other labour market rules and policies, for example, because of recognition that their absence leads to precarious work, ${ }^{85}$ their use as instruments to induce, or compel, economic calculation on the part of workers may remain.

Labour market flexibility is a rationality that combines a sensibility about the primacy of market principles and forces in the functioning of the labour market with a new idea about the subjectivity of the worker and an image of the relationship of the worker to both her work and herself. On one level, it expresses the enduring, if ahistorical, hope that labour can be treated as a commodity like any other, here following a general

81 See, for example, Laval un Partneri [2007] ECR I-11767; Ruffert [2008] ECR I-1989; The International Transport Workers' Federation and The Finnish Seamen's Union [2007] ECR I-10779 ('Viking'). See also Kerry Rittich, 'Core Labour Rights and Labour Market Flexibility: Two Paths Entwined?', Labor Law Beyond Borders: ADR and the Internationalization of Labor Dispute Resolution Permanent Court of Arbitration/Peace Palace Papers (Kluwer Law International 2003); Diamond Ashiagbor, 'Collective Labour Rights and the European Social Model' (2009) 3 Law and Ethics of Human Rights 223-66.

82 For an example of this phenomenon in the context of EU employment policy, see the discussion of the requirement that workers invest in their 'employability' in Ashiagbor (n 48) ch 2.

83 Philip Alston and Mary Robinson (eds), Human Rights and Development: Towards Mutual Reinforcement (Oxford University Press 2005).

84 Safarty (n 52); Santos (n 12).

85 World Bank, World Development Report 2013 (n 1) 262. For a response, see the ILO statement at <www.ilo.org/wcmsp5/groups/public/_ed_emp/_ed_emp_msu/documents/statement/ wcms_192350.pdf>. 
governance trend in which all markets mirror the stock market. ${ }^{86}$ The significance of this rationality is perhaps best captured by recalling that, as a field or discipline, labour law was born of the opposite sensibility or consciousness. It was premised on the understanding that market forces need to be interrupted and countervailing forces unleashed if the characteristic problems and predicaments of workers and citizens - substandard terms and conditions of work, lack of voice and control over the labour contract and pervasive economic insecurity - were to be overcome. ${ }^{87}$ But flexibility also underwrites a particular image of work and the work relationship at the micro-level. What drives the flexibility agenda is not simply a process of recommodification; rather, its engine is the cultivation of infinite responsiveness to market signals on the part of the worker. From the standpoint of the policy-maker, the worker is not simply the homo oeconomicus of economic theory, the rational calculator who is constantly maximising his welfare or utility, broadly defined. Nor is he encouraged to minutely parse the exchange value of his labour; if he did so, he might notice that under current labour market norms, he is assuming a lot of risk for little or diminishing economic reward.

In legal terms, flexibility is a proxy for enhanced employer legal powers, both in the workplace and in the terms and conditions of employment. Flexibility is effected through the simultaneous institutionalisation of entitlements benefiting employers and the preclusion or deinstitutionalisation of countervailing legal entitlements that workers might otherwise deploy in the course of bargaining over the labour contract. Despite the argument that the resulting labour markets are devoid of 'distortions', the constitutive, and variable role played by institutions in markets means that flexibility can only be an attempt to naturalise an inherently contingent and contestable baseline of legal rights to employers' advantage. Mere recognition of workers' rights in the abstract, moreover, does not necessarily disturb these processes of institutionalisation and deinstitutionalisation, nor, it follows, does it necessarily change the balance of power in the course of contracting.

Distracted from the element of bargain or exchange, the worker is encouraged to imagine himself as an 'entrepreneur of himself', 88 operating in a field in which reward is commensurate with the investment of time, skill and effort. It is but a short step to move from a labour model to an entrepreneurial model of work altogether. At this point the worker is imagined in terms of his 'capital ability', 89 that is, in terms of his capacity to generate a future income stream. From there, it is but another short step to move to social programmes that aid, even require, people to invest in these capacities and processes. All of these moves, I suggest, now visibly shape contemporary labour and social policy.

\section{The market as the new social}

The claim that we are now in a 'knowledge economy' in which labour market success is a function of individual skill and education has become conventional wisdom and now approaches the status of inviolable truth. ${ }^{90}$ On one level, this claim simply reflects a set of

86 'Every market, whether for airline tickets or for human labor, has been or is being restructured to resemble the constantly fluid world of Wall Street, in which prices float freely and arrangements are as impermanent as possible.': Douglas Henwood, Wall Street: How it Works and for Whom (Verso 1997).

87 O Kahn-Freund, Labour and the Law (Stevens 1972); Karl Klare, 'Countervailing Workers' Power as a Regulatory Strategy' in H Collins, Paul Davies and Roger Rideout (eds), Legal Regulation of the Employment Relation (Kluwer Law International 2000).

88 Foucault (n 8).

89 Ibid 225.

90 Courchene (n 75); World Bank, Building Knowledge Economies (n 74). 
interrelated sociological observations, for example: that returns to skill are greater in a globalised as opposed to closed national economy; that skilled work is more highly valued in post-industrial, technologically intensive economies than industrial ones; and that knowledge is a core attribute of success in increasingly dynamic economies. ${ }^{91}$ But the focus on knowledge also has a theoretical grounding: it comports with a core neoclassical premise that market returns to labour track workers' marginal contribution to productive activity.

The policy implications of this focus on knowledge, however, are quite uncertain. The contribution of workers, whether individual or as a collective, to joint productive processes is inherently unstable and contestable, given that the value of all productive inputs is partly determined by law. ${ }^{92}$ The commitment to the knowledge economy does not, in any event, appear to have led to dramatically enhanced attention to funding for education and training; nor has it yet induced regulators and policy-makers to change the legal incentives and requirements when it comes to the training of workers.

It is easier to identify the negative imprint of the focus on knowledge. First, it appears to successfully weaken the case for traditional social responses to deficits in respect of the quality, remuneration or simply levels of jobs. A focus on knowledge need not deflect attention from issues like bargaining power, access to resources, social capital and the strength of worker networks and associations - indeed, arguments for renewed, even enhanced, attention to such questions can and have been made. ${ }^{93}$ However, it does provide a framework in which market returns can be detached from the legal and institutional arrangements that configure the bargaining power of the parties to the work relationship and attributed to the quality (or lack thereof) of the workforce itself. However the work relationship is understood, a knowledge focus orients the tasks of labour market policy and labour market institutions in a quite specific way: their function is to produce more economically 'useful' workers, workers that are, moreover, responsive rather than resistant to market forces.

The second consequence is the emergence of entrepreneurialism as an element of labour policy. Entrepreneurialism, once indelibly associated with the very thing that labour market regulation was against, has now been integrated into the heart of labour policy. As it becomes clear, given the ongoing stagnation of growth in advanced economies, ${ }^{94}$ that jobs may simply not materialise for everyone in the labour market, greater entrepreneurial skills and energy by workers are imagined as playing a central part in solving the contemporary problems of work. Entrepreneurial attitudes are not just an essential part of the cooperation between employers and employees needed for success in a dynamic economy; simply put, some workers may need to employ themselves. Whether and how entrepreneurialism can be fostered through policy interventions are now central concerns of the major institutions concerned with labour market governance like the World Bank and the ILO. ${ }^{95}$

91 Katherine Van Wezel Stone, From Widgets to Digits: Employment Regulation for the Changing Workplace (Cambridge University Press 2004); World Bank, Building Knowledge Economies (n 74).

92 Felix Cohen, 'Transcendental Nonsense and the Functional Approach' (1935) 39 Columbia Law Review 809.

93 Deakin and Wilkinson, The Law of the Labour Market (n 62); Katherine van Wezel Stone, 'The Future of Labor and Employment Law in the United States' in K Dau-Schmidt (ed), Encyclopedia of Labor and Employment Law and Economics (Edward Elgar 2008).

94 John Bellamy Foster and Robert W McChesney, The Endless Crisis: How Monopoly Finance-Capital Produces Stagnation and Upheaval from the US to China (Monthly Review Press 2012).

95 World Bank, World Development Report 2013: Jobs. The ILO, in its Decent Work Agenda, states that creating jobs requires an economy that 'generates opportunities for investment, entrepreneurship, skills development, job creation and sustainable livelihoods'. <www.ilo.org/global/about-the-ilo/decent-workagenda/lang-en/index.htm>. 
The continuities between employees and other market actors with whom they share key characteristics such as economic dependence and subordination have been a central, and vexed, subject in labour and employment law for some time. ${ }^{96}$ One familiar angle of response among labour lawyers is a call for the extension of at least some labour market institutions and protections to those such as 'dependent contractors' who, like employees, have limited autonomy, control and bargaining power at work. ${ }^{97}$ But the rise of entrepreneurialism as an attribute to be cultivated among workers makes it clear that the task can be envisioned in the opposite way: rather than assimilate such workers to the category of employees, distinctions between workers and other market actors can be bridged or broken down by treating all workers simply as commercial actors.

A third consequence is the explicit mobilisation of social programmes to foster the creation of human capital for purposes of economic development and the (related) infusion of economic incentives and market logics into social projects and endeavours. Here, any distinction between social and economic policy becomes progressively more difficult to maintain. Since the early 1990s, the use of market incentives to increase levels of labour market participation and to induce workers to return quickly to the labour market have played a central role in labour and social policy reforms. ${ }^{98}$ States have been repeatedly counselled to curtail access to employment insurance through the adoption of longer labour market qualification periods; to reduce levels of replacement income in order to 'make work pay'; 99 and to condition the receipt of any social benefits on the search for work or participation in schemes to enhance human capital through skills and training. ${ }^{100}$ Outside the industrialised world, however, the main focus has been elsewhere. In contexts where conventional social policies reach only a minority of the population, where many people labour in informal markets and where significant amounts of economic activity take place outside of markets altogether, proposals range from the formalisation of informal markets in labour and land ${ }^{101}$ to the promotion of microcredit programmes $^{102}$ and other projects to advance the goals of financial inclusion ${ }^{103}$ and the use of conditional cash transfers to households to incentivise investments in the future productivity and human capital of children. ${ }^{104}$ There are now diverse, and burgeoning, social projects emanating from the identification of human capital as a key factor in better labour market outcomes, all of which are designed to imprint and deepen this logic of

96 Hugh Collins, 'Independent Contractors and the Challenge of Vertical Disintegration to Employment Protection Laws' (1990) 10 Oxford Journal of Legal Studies 353-80.

97 Guy Davidov, 'The Three Axes of Employment Relationships: A Characterization of Workers in Need of Protection' (2002) 52 University of Toronto Law Journal 357-418.

98 OECD, OECD Jobs Study (n 46); Rittich (n 48); OECD, Boosting Jobs and Incomes (n 46).

99 OECD, OECD Jobs Study (n 46); OECD, Boosting Jobs and Incomes (n 46); Weisbrot and Jorgenson (n 51).

100 Standing (n 48).

101 Klaus Deininger, Land Policies for Growth and Poverty Reduction (World Bank/Oxford University Press USA 2003) <http://econ.worldbank.org/external/default $/$ main?pagePK=64165259\&theSitePK $=469372$ \&piPK=64165421\&menuPK=64166093\&entityID=000094946_0307250400474>; UNDP (n 73).

102 See Microcredit Summit Campaign <www.microcreditsummit.org/about/what_is_microcredit>;

103 World Bank, Finance for All? Policies and Pitfalls in Expanding Access (World Bank 2007) <http://go.worldbank.org/HNKL9ZHO50>; Ambreena Manji, 'Eliminating Poverty? "Financial Inclusion", Access to Land, and Gender Equality in International Development' (2010) 73 Modern Law Review 985-1004.

104 Maxine Molyneux, 'Mothers at the Service of the New Poverty Agenda: Progresa/Opportunidades, Mexico's Conditional Transfer Programme' (2006) 40 Social Policy and Administration 425-49; Helena Alviar, 'Legal Reform, Social Policy, and Gendered Redistribution in Colombia: The Role of the Family' (2010) 19 Journal of Gender, Social Policy and the Law 101-23; Rittich (n 39). 
responsiveness to market signals within households. The same goals and logic are now visible in gender equality and gender empowerment initiatives as well. ${ }^{105}$

This explicit fusion of the social with the market is visible in projects of legal empowerment', an idea popularised by the Commission on Legal Empowerment of the Poor. ${ }^{106}$ Built on the idea that legal formality brings a host of benefits to the poor, such initiatives advocate the adoption of the 'rule of law' as a central tool in poverty alleviation and the achievement of better social welfare outcomes. Informing this approach is an image of the exemplary poor person, one with inherent talents and tendencies toward entrepreneurialism that need only be 'unleashed' by the right legal reforms in order for poverty to be defeated. Thus, poverty alleviation occurs principally through the mobilization of market forces and the extension of market opportunities to those who are either outside markets altogether or perceived to be disadvantaged within them because of the absence of enforceable legal rights and/or dysfunctional and predatory forms of regulation ${ }^{107}$ Law plays its classic intermediating role in these projects, ensuring certainty of economic reward for effort and smoothing the way for efficient transactions in the marketplace.

Notice where we have arrived: rather than the social as against the market, we now have the market as a social force. Market incentives not only restructure the encounter between individuals and labour markets; they reach deep into the fabric of the household, modifying the behaviour of family members and sometimes the household structure as well. Not only is the market imagined as the basis of better social outcomes; social and economic objectives have become essentially coterminous. In some places, there is little visible distinction between them remaining. To return to Foucault, with labour market flexibility and market-centred social projects we appear to have moved from homo oeconomicus, the subject with interests who makes choices, to the subject who is infinitely governable. Indeed, Foucault saw this paradoxical result as the endpoint of liberal governmentality. 108

\section{Revisiting the social and the market}

If the generalisation of market principles has reconfigured the idea about what social programmes look like, indeed what they are for, what does this mean both in general and for the field of labour law?

In the neoliberal imaginary, as flexibility policies are implemented and workers become more skilled - 'better at what they do' - they are sequentially deployed in more productive ways that ultimately produce welfare gains across the board. ${ }^{109}$ Labour market flexibility is a normalisation project; it is not necessary to believe that it will succeed in its objectives to foresee how it might be effective in a range of ways. One is the creation of more precarious work; ${ }^{110}$ indeed, events like increased economic insecurity, diminished voice and influence for workers, and degraded terms and conditions of work are so foreseeable that, if they are not the actual intent of greater labour market flexibility, then

105 See, for example, the Calvert Women's Principles at <www.calvert.com/sri-women.html>, as of 2010 the UN Women's Empowerment Principles. See also <www.unglobalcompact.org/issues/human_rights/ equality_means_business.html>.

106 UNDP (n 72).

107 Hernando De Soto, The Other Path: The Invisible Revolution in the Third World, June Abbott (trans) (Harper \& Row 1989). For a discussion, see Haldar in this volume.

108 Foucault (n 8) 270-1.

109 See, for example, the description introducing the World Bank, World Development Report 2013 (n 1).

110 Rittich, 'Rights, Risk and Reward' (n 48). 
they must be taken as willingly assumed risks. ${ }^{111}$ But the reconfiguration of labour market institutions enables other outcomes too. Approached as devices that not only establish employer and employee freedoms and prohibitions and allocate costs, risk and benefits among them, labour market rules and regulations can be used to actively reshape the worker and her relation to work and the market; this same discovery holds possibilities for transforming the relation of the market to the social in general.

The challenges to labour law and to the settled idea of the social by such uses of labour market institutions seem clear. Post-war labour and social policy were premised on the understanding that workers constitute a distinct social and economic class that stands in opposition to capital. However, the assimilation of labour markets into the general category, 'the market', means that no distinctive properties or rationalities need be attributed to either workers or labour markets. It also means that workers' identities as workers are not taken as fixed; nor do workers or their associations possess special interests that need to be recognized. Indeed, the identification of workers primarily as individual market actors collapses much of the fundamental opposition between labour and capital. Instead of mediating between conflicting interests and identities, labour market reforms present an opportunity not just to change the behaviour but to remake the subjectivity of the worker and to induce her to revalue her interests tout court.

At this point, we have to confront, as Foucault put it, 'the problem of the inversion of the relationship of the social to the market'. ${ }^{112}$ The conscious effort to manage labour markets so as to (try to) produce subjects and citizens who are instrumentalised in the service of economic efficiency and growth, even as they are recognised as individuals with 'rights', also clarifies as a by-product of something about the nature of the social. If the relation of the social to the market is not fixed but transitory and if social formations emerge in relation to political forces and projects, then governance projects like flexibility may both impede and enable the creation, even the imagination, of different forms of associations, political, economic, industrial and other. Perhaps under the radically individualising and fragmenting logic of flexibility, society cannot be presumed to be a singular or cohesive force that will rise up against the market. For example, workers may not understand themselves as communities with interests; they may not see themselves as a particular class, or even as workers at all. ${ }^{113}$

One of the conundrums of acute interest to contemporary scholarship on the regulation of markets, including labour markets, is the resilience of claims about the effects of legal institutions where evidence is equivocal or even where it appears to be directly contradictory. ${ }^{114}$ Sometimes new evidence does shift the argument, but surprisingly often it does not: conventional wisdom often remains in circulation quite independent of the factual claims on which it rests. ${ }^{115}$ The recognition of a distinct rationality or epistemology for labour market policy provides one vantage point from which to appreciate this phenomenon. It also serves as at least a partial corrective to what might be called 'naïve' legal or economic sociology - that is, attempts to resolve disputes about the appropriate forms of labour market regulation simply by establishing 'the facts'.

111 Standing (n 48); Guy Standing, The Precariat: The New Dangerous Class (Bloomsbury Academic 2011).

112 Foucault (n 8) 240.

113 Harry Arthurs, 'Making Bricks Without Straw: The Creation of a Transnational Labour Regime' in G De Burca, C Kilpatrick and J Scott (eds), Global Governance: Critical Legal Perspectives: Liber Amicorum David $M$ Trubek (Hart 2014).

114 John Quiggin, Zombie Economics: How Dead Ideas Still Walk among Us (Princeton University Press 2010).

115 Thomas Kuhn, The Structure of Scientific Revolutions (University of Chicago Press 1962); Bruno Latour, We Have Never Been Modern (Harvard University Press 1993). 
Some questions may, of course, be resolved by more empirical knowledge. But, if facts materialise differently within different cognitive frameworks, or if they are perceived to be relevant only within particular normative and analytic frameworks, then they can both gain and lose significance quite apart from their status in the 'real' world. They can become truths that can be mobilised to help build the very world that they purport to merely describe. In the alternative, they may disappear from view, surfacing, and persuading, again only when events have provoked a shift in the logic or rationality that presently obscures them from view. 
